\title{
NITROGEN RATES AND RESIDUAL EFFECT OF CO-INOCULATION OF SOYBEAN ON MAIZE PLANTS ${ }^{1}$
}

\author{
AUREANE CRISTINA TEIXEIRA FERREIRA CÂNDIDO ${ }^{2 *}$, MARCO ANTONIO CAMILLO DE CARVALHO ${ }^{3}$, \\ RICARDO ADRIANO FELITO ${ }^{4}$, ADRIANO MALTEZO DA ROCHA ${ }^{5}$, OSCAR MITSUO YAMASHITA ${ }^{3}$
}

\begin{abstract}
Co-inoculation consists of using microorganism combinations with synergic effect that surpass the results obtained with their use alone. The objective of this work was to evaluate the effect of inoculation and co-inoculation on soybean plants, and their residual effect on maize plants grown intercropped with ruzigrass (Urochloa ruziziensis), under different $\mathrm{N}$ fertilizer rates. The experiment was conducted at the experimental area of the Mato Grosso State University, Alta Floresta campus, in a Typic Hapludox. A randomized block design was used for the soybean crops; the treatments consisted of Bradyrhizobium japonicum inoculated single, or co-inoculated with Azospirillum brasilense, with 20 replications. A randomized block design in a strip-plot arrangement was used for the winter maize-ruzigrass intercrop (WMRI); the treatments consisted of combination of residual effect of inoculation and co-inoculation in the strips, and five $\mathrm{N}$ fertilizer rates $\left(0,50,100,150\right.$, and $\left.200 \mathrm{~kg} \mathrm{ha}^{-1}\right)$ in plots with WMRI, with four replications. The co-inoculation of soybean seeds and its residual effect on the maize crops increased the root dry weight of plants of both crops; however, no increases were found for most vegetative and reproductive characteristics of maize plants. Yield and most characteristics evaluated had increasing linear responses to increases in $\mathrm{N}$ rates, indicating the plants could respond to rates above $200 \mathrm{~kg} \mathrm{ha}^{-1}$.
\end{abstract}

Keywords: Intercrop. Urochloa ruziziensis. Azospirillum brasilense. Nitrogen Fertilization.

\section{DOSES DE NITROGÊNIO NO MILHO CONSORCIADO COM FORRAGEIRA, SOB EFEITO RESIDUAL DA COINOCULAÇÃO NA SOJA}

RESUMO - A coinoculação consiste no uso de combinações de micro-organismos, os quais produzem efeito de sinergismo, ultrapassando resultados produtivos obtidos de forma isolada. Objetivou-se avaliar o efeito da inoculação e coinoculação sobre a cultura da soja e seus reflexos sobre a cultura do milho sob doses de nitrogênio $(\mathrm{N})$ no sistema de consórcio milho + braquiária. O experimento foi instalado na área experimental da Universidade do Estado de Mato Grosso - UNEMAT, Campus de Alta Floresta em LATOSSOLO VERMELHO-AMARELO Distrófico. Para a cultura da soja o delineamento utilizado foi blocos ao acaso, sendo os tratamentos constituídos pela inoculação com Bradyrhizobium japonicum com e sem a coinoculação com Azospirillum brasilense, com vinte repetições cada. O delineamento para cultura do milho foi em faixa, sendo os tratamentos experimentais constituídos pela combinação do resíduo da inoculação e da coinoculação na faixa e cinco doses de $\mathrm{N}\left(0,50,100,150\right.$ e $\left.200 \mathrm{~kg} \mathrm{ha}^{-1}\right)$, aplicadas no milho safrinha consorciado com Urochloa ruziziensis nas parcelas, com quatro repetições. A coinoculação das sementes de soja e o resíduo da coinoculação no milho elevaram a massa seca da raiz para as duas culturas, porém esse incremento não se deu para a maioria das características vegetativas e reprodutivas avaliadas no milho. Para a produtividade e também para a maioria das características avaliadas ocorreu resposta linear crescente com o aumento das doses de $\mathrm{N}$ aplicadas, indicando que poderia haver respostas a doses superiores a $200 \mathrm{~kg} \mathrm{ha}^{-1}$.

Palavras-chave: Consórcio. Urochloa ruziziensis. Azospirillum brasilense. Adubação nitrogenada.

\footnotetext{
*Corresponding author

${ }^{1}$ Received for publication in $07 / 27 / 2019$; accepted in 04/23/2020.

Paper extracted from the master's thesis of the first author.

${ }^{2}$ Graduate Program in Society, Nature, and Development, Universidade Federal do Oeste do Pará, Santarém, PA, Brazil; aurianeferreira@hotmail.com - ORCID: 0000-0001-7540-1325.

${ }^{3}$ Department of Agronomy, Universidade do Estado de Mato Grosso, Alta Floresta, MT, Brazil; marcocarvalho@unemat.br - ORCID: 0000-0003-4966-1013, yama@unemat.br-ORCID: 0000-0001-6715-626X.

${ }^{4}$ Graduate Program in Agronomy, Universidade Estadual Paulista Júlio de Mesquita Filho, Botucatu, SP, Brazil; ricardofelito@hotmail.com - ORCID: 0000-0002-8323-4720.

${ }^{5}$ Graduate Program in Agronomy, Universidade Estadual Paulista Júlio de Mesquita Filho, Jaboticabal, SP, Brazil; admr.maltezo@hotmail.com-ORCID:0000-0002-0032-0034.
} 


\section{INTRODUCTION}

Inoculation of soybean crops with bacteria of the genus Bradyrhizobium is practiced by soybean producers because it is one of the determinant factors to reach high yields without using soil $\mathrm{N}$ fertilization, and biological $\mathrm{N}$ fixation is a sustainable source of this nutrient (FIPKE et al., 2016).

In addition to the several benefits of inoculation, other alternative technologies have been studied, such as co-inoculation (ZUFFO et al., 2015).

Bacteria of the genus Bradyrhizobium have been used combined with bacteria of the genus Azospirillum. Azospirillum bacteria assist in overcome environmental stresses (CHIBEBA et al., 2015) when inoculated or co-inoculated in seeds of plants, improving seed germination, plant growth, and root ramification and nodulation (JUGE et al., 2012).

However, the residual effect of their inoculation and co-inoculation on the succeeding crops should be elucidated, since inoculation of maize seeds with Azospirillum brasilense, for example, can increase winter maize yield due to biological $\mathrm{N}$ fixation, and can contribute to the positive balance of $\mathrm{N}$ for the succeeding crop (JORDÃO et al., 2011).

Moreover, the $\mathrm{N}$ rate to be applied to winter maize is still not clear, since studies (BASTOS et al., 2008, KAPPES et al., 2009, SORATTO et al., 2010) have shown great variation in maize responses to $\mathrm{N}$ fertilization, with the higher yields for the rates of 70 to $180 \mathrm{~kg} \mathrm{ha}^{-1}$ of $\mathrm{N}$.

Thus, studies on co-inoculation of soybean seeds with $A$. brasilense and its residual effects on the succeeding crop (usually maize grown single, or intercropped with other grass species) are important. Recommendations focused on techniques commonly used (mineral fertilization) and recently incorporated (inoculation of grass seeds with diazotrophic bacteria) to production systems became the issue of many studies (SABUNDJIAN, 2016). However, these studies also require the integration of these techniques prioritizing the sustainability of the agroecosystems.

Thus, the objective of this work was to evaluate the effect of Bradyrhizobium japonicum inoculated single or co-inoculated with Azospirillum brasilense on soybean plants, and their residual effect on vegetative and reproductive characteristics of maize plants grown intercropped with ruzigrass (Urochloa ruziziensis), under different $\mathrm{N}$ fertilizer rates.

\section{MATERIAL AND METHODS}

The experiment was conducted at the experimental area of the Mato Grosso State University (UNEMAT), Alta Floresta campus $\left(09^{\circ}\right.$ $51^{\prime} 42^{\prime \prime} \mathrm{S}$ and $56^{\circ} 04^{\prime} 07^{\prime \prime} \mathrm{W}$, and altitude of 283 meters). The predominant climate of the region is Am, according to the Köppen classification, with two well-defined climatic seasons, and mean annual rainfall depth of 2,400 $\mathrm{mm}$, with higher intensity in January to March, and five months with water deficit (EPE, 2009).

The study area had been grown with Urochloa brizantha cv. Marandu. The soil of area was classified as Typic Hapludox (Latossolo Vermelho-Amarelo distrófico típico; EMBRAPA, 2013). Samples of the soil $0-0.20 \mathrm{~m}$ layer were collected in July 2015; 20 simple samples formed a composite sample to determine chemical and granulometric characteristics, focused on determining the soil fertilizer rates to be used. The results showed $23.0 \mathrm{~g} \mathrm{dm}^{-3}$ of organic matter, $\mathrm{pH}$ $\left(\mathrm{CaCl}_{2}\right)$ of $5.22,1.22 \mathrm{mg} \mathrm{dm}^{-3}$ of P (Mehlich 1), 0.29 cmolc $\mathrm{dm}^{-3}$ of K, $2.19 \mathrm{cmolc} \mathrm{dm}^{-3}$ of $\mathrm{Ca}, 0.98 \mathrm{cmolc}$ $\mathrm{dm}^{-3}$ of $\mathrm{Mg}, 0.00 \mathrm{cmolc} \mathrm{dm}^{-3}$ of $\mathrm{Al}, 2.55 \mathrm{cmolc} \mathrm{dm}^{-3}$ of $\mathrm{H}$, cation exchange capacity (CEC $\mathrm{pH} 7)$ of 6.01 cmolc $\mathrm{dm}^{-3}$, and base saturation of $57.6 \%$. The granulometric analysis showed $396 \mathrm{~g} \mathrm{~kg}^{-1}$ of clay, $140 \mathrm{~g} \mathrm{~kg}^{-1}$ of silt, and $474 \mathrm{~g} \mathrm{~kg}^{-1}$ sand, denoting a sandy-clay texture. According to the recommendations in Novais (1999), liming was not needed.

A randomized block experimental design was used for soybean crops, with treatments consisted of Bradyrhizobium japonicum inoculated single, or coinoculated with Azospirilum brasilense, with 20 replications. A randomized block experimental design in a strip-plot arrangement was used for the winter maize-ruzigrass (Urochloa ruziziensis) intercrop (WMRI), with 10 treatments and four replications. The experimental area had $1,680 \mathrm{~m}^{2}$, each subplot presented $6 \mathrm{~m}$ width and $7 \mathrm{~m}$ length, with a total of 40 subplots.

The treatments for the maize consisted of combination of residual effect of Bradyrhizobium japonicum inoculated single, and co-inoculated with Azospirillum brasilense in the strips (main factor), and five $\mathrm{N}$ rates $\left(0,50,100,150\right.$, and $\left.200 \mathrm{~kg} \mathrm{ha}^{-1}\right)$ in the plots (secondary factor). Each plot consisted of 12 seven-meter soybean or maize rows spaced $0.5 \mathrm{~m}$ apart. The evaluation area of each plot consisted of the four central rows, disregarding $1.0 \mathrm{~m}$ from both ends, totaling an area of $10 \mathrm{~m}^{2}$ for each plot.

Soybean seeds were sowed on December 08, 2015, using the cultivar TMG133-RR, with spacing of $0.5 \mathrm{~m}$ between rows for a population of 280,000 plants $\mathrm{ha}^{-1}$. Sowing fertilization was carried out according to recommendations of Novais (1999), using $400 \mathrm{~kg} \mathrm{ha}^{-1}$ of the 00-30-20 (N-P-K) formulation. The seed inoculation was carried out before sowing, using $80 \mathrm{~g}$ of Nitro Geo ${ }^{\circledR}$ (SEMIA5079 and SEMIA-5080 strains) for $50 \mathrm{~kg}$ of seeds; and the co-inoculation was carried out using $80 \mathrm{~g}$ of 
Nitro Geo Soja Turfa ${ }^{\circledR}$ (SEMIA-5079 and SEMIA5080 strains) for $50 \mathrm{~kg}$ of seeds plus $100 \mathrm{~mL}$ of Nitro Geo $\mathrm{AZ}^{\circledR}$ (AbV5 and AbV6 strains) for $25 \mathrm{~kg}$ of seeds.

Soybean plants were evaluated for leaf $\mathrm{N}$ content (MALAVOLTA; VITTI; OLIVEIRA, 1997); root length, weight, and volume; and shoot length and weight.

Maize seeds were sowed soon after the soybean harvest, on May 14, 2016, with no soil tillage. The 2B877-PW (simple hybrid) maize cultivar was used; the spacing between rows was 0.5 $\mathrm{m}$ for a population of 55,000 plants $\mathrm{ha}^{-1}$. Sowing fertilization was carried out according to recommendations of Alves et al. (1999), applying 16 $\mathrm{kg} \mathrm{ha}^{-1}$ of $\mathrm{N}, 120 \mathrm{~kg} \mathrm{ha}^{-1}$ of $\mathrm{P}_{2} \mathrm{O}_{5}$, and $48 \mathrm{~kg} \mathrm{ha}^{-1}$ of $\mathrm{K}_{2} \mathrm{O}$, using the 04-30-12 (N-P-K) formulation.

The maize crop was grown intercropped with ruzigrass (Urochloa ruziziensis). The ruzigrass seeds were sowed simultaneously to the maize crop, using $12 \mathrm{~kg}$ of seeds per hectare. The ruzigrass seeds were mixed to the soil fertilizer and placed in the fertilizer compartment of the seeder, placing them at the same depth of the fertilizer. Topdressing was carried out when the maize crop reached the phenological stage V6 (six fully developed leaves), on June 06, 2016; the $\mathrm{N}$ rates were applied manually according to the treatments $\left(0,50,100,150\right.$, and $\left.200 \mathrm{~kg} \mathrm{ha}^{-1}\right)$, using urea $(45 \% \mathrm{~N})$ as $\mathrm{N}$ source. The $\mathrm{N}$ rate recommended for the soil conditions was $100 \mathrm{~kg} \mathrm{ha}^{-1}$, according to Alves et al. (1999).

The WMRI was under a conventional irrigation system, with water supply according to the needs of the crop, reaching the maximum water depth of $7 \mathrm{~mm}$ day $^{-1}$.
The maize ears were manually harvested on August 24, 2016, colleting the ears of the evaluation area of each plot. The ears of plants outside the evaluation area were removed from the area to avoid interferences with the ruzigrass development.

The maize plants were evaluated for root length, weight, and volume; shoot length and weight; plant height; first ear insertion height; stem diameter; threshed ear length and diameter; number of grains per ear; grain yield; and 1000-grain weight.

During the collection of the plants, they were evaluated for SPAD index through five readings by a chlorophyll meter (SPAD 502, Minolta) on the $3^{\text {rd }}$ fully developed leaf from the apex in the main stem, using ten plants per plot.

The data of all the evaluations were subjected to analysis of variance, the means of the qualitative factor (inoculation) were compared by the F test, and means of the quantitative factor ( $\mathrm{N}$ rates) were subjected to polynomial regression, using the Sisvar program (FERREIRA, 2011).

\section{RESULTS AND DISCUSSION}

The results found for the evaluated characteristics during the full flowering of the soybean crops are presented in Table 1. In the flowering stage, when the highest accumulation of dry matter per plant occurs, the root length was not affected by the co-inoculation. The other variables (shoot length, shoot dry weight, root dry weight, root volume, and leaf $\mathrm{N}$ content) increased when using inoculation with Azospirillum brasilense.

Table 1. Root length, shoot length, shoot dry weight, root dry weight, root volume, and leaf $\mathrm{N}$ content of soybean plants at the full flowering stage as a function of seed inoculation with Bradyrhizobium japonicum (BJ), and co-inoculation with Azospirillum brasilense (BJ+AB).

\begin{tabular}{ccccccc}
\hline Treatment & $\begin{array}{c}\text { Root length } \\
(\mathrm{cm})\end{array}$ & $\begin{array}{c}\text { Shoot length } \\
(\mathrm{cm})\end{array}$ & $\begin{array}{c}\text { Shoot dry weight } \\
(\mathrm{g})\end{array}$ & $\begin{array}{c}\text { Root dry weight } \\
(\mathrm{g})\end{array}$ & $\begin{array}{c}\text { Root volume } \\
\left(\mathrm{cm}^{3}\right)\end{array}$ & $\begin{array}{c}\text { Leaf N content } \\
\left(\mathrm{g} \mathrm{kg}^{-1}\right)\end{array}$ \\
\hline BJ & $36.00 \mathrm{a}$ & $67.58 \mathrm{~b}$ & $21.76 \mathrm{~b}$ & $2.38 \mathrm{~b}$ & $5.80 \mathrm{~b}$ & $42.46 \mathrm{~b}$ \\
$\mathrm{BJ}+\mathrm{AB}$ & $36.50 \mathrm{a}$ & $70.28 \mathrm{a}$ & $32.33 \mathrm{a}$ & $3.07 \mathrm{a}$ & $8.07 \mathrm{a}$ \\
\hline $\mathrm{CV}(\%)$ & 17.71 & 5.26 & 28.02 & 21.86 & 19.54 & $45.62 \mathrm{a}$ \\
MSD & 4.11 & 2.32 & 4.85 & 0.38 & 0.87 & 3.68 \\
F value & $0.06^{\mathrm{ns}}$ & $5.56^{*}$ & $19.47^{* *}$ & $13.50^{* *}$ & $28.16^{* *}$ & 1.52 \\
\hline
\end{tabular}

Means followed by the same letter are not significantly different by the $\mathrm{F}$ test $(p<0.05) . \mathrm{ns}, * *, *=$ not significant, significant at $p<0.01$, and significant at $p<0.05$ by the $\mathrm{F}$ test; $\mathrm{CV}=$ Coefficient of variation; $\mathrm{MSD}=$ minimum significant difference.

According to Barassi et al. (2008), A. brasilense bacteria cause changes in leaf photosynthetic variables, including chlorophyll content and stomatal conductance, increase proline contents in shoots and roots, water potential, apoplast water content, cell wall elasticity, biomass production, and plant height, as found in the present study, which showed increases in shoot and root weights and in $\mathrm{N}$ contents. These effects improve plant development, denoted by the high root development found for the soybean plants. 
The plant height, stem diameter, and shoot dry weight of maize plants were not affected by the residual effect of inoculation, which affected the first ear insertion height (Table 2). The $\mathrm{N}$ rates affected stem diameter and SPAD index. The interaction between inoculation and $\mathrm{N}$ rates was not significant for any of the variables (Table 2).

Table 2. Plant height, first ear insertion height, stem diameter, SPAD index, and shoot dry weight as a function of $\mathrm{N}$ rates and residual effect of seed inoculation and co-inoculation on maize crops succeeding soybean crops.

\begin{tabular}{lccccc}
\hline Source of variation & $\begin{array}{c}\text { Plant height } \\
(\mathrm{m})\end{array}$ & $\begin{array}{c}\text { First ear insertion height } \\
(\mathrm{m})\end{array}$ & $\begin{array}{c}\text { Stem diameter } \\
(\mathrm{mm})\end{array}$ & $\begin{array}{c}\text { SPAD } \\
\text { index }\end{array}$ & $\begin{array}{c}\text { Shoot dry weight } \\
(\mathrm{g})\end{array}$ \\
\hline F value & & & & & \\
Inoculation (I) & $0.59^{\mathrm{ns}}$ & $346.8^{* *}$ & $0.27^{\mathrm{ns}}$ & $0.28^{\mathrm{ns}}$ & $0.05^{\mathrm{ns}}$ \\
N rates (N) & $1.11^{\mathrm{ns}}$ & $1.682^{\mathrm{ns}}$ & $5.17^{*}$ & $25.14^{* *}$ & $0.85^{\text {ns }}$ \\
$\mathrm{I} \times \mathrm{N}$ & $0.44^{\mathrm{ns}}$ & $0.63^{\mathrm{ns}}$ & $1.11^{\mathrm{ns}}$ & $1.06^{\mathrm{ns}}$ & $0.78^{\mathrm{ns}}$ \\
\hline CV 1 (\%) & 2.11 & 0.52 & 0.77 & 0.71 & 8.19 \\
CV 2 (\%) & 2.57 & 3.69 & 2.04 & 2.31 & 18.74 \\
CV 3 (\%) & 2.44 & 3.16 & 1.94 & 1.99 & 14.84 \\
\hline Overall mean & 1.94 & 1.10 & 20.24 & 55.77 & 159.56 \\
\hline
\end{tabular}

$\mathrm{ns}, * *, *=$ not significant, significant at $p<0.01$, and significant at $p<0.05$ by the $\mathrm{F}$ test; $\mathrm{CV}=$ Coefficient of variation.

Significant residual effect of co-inoculation on plant height (Table 2) is a characteristic of high genetic heritability (DARTORA et al., 2013) that can also be affected by the environment and nutrient availability. Thus, treatments were balanced from the vegetative development to the flowering stage because of the residual effect of co-inoculation and $\mathrm{N}$ rates. The $\mathrm{N}$ rates had no effect on plant height due to the co-inoculation, which may have promoted the development of the plants' root system even using the lowest $\mathrm{N}$ rates, improving the plants' nutrient absorption capacity, as reported by Albuquerque et al. (2013).

The similar plant heights and different first ear insertion heights due to the residual effect of coinoculation (Table 3) can be explained by the topdressing, which improved plant nutrition in the treatments. According to Dobbelaere, Vanderleyden and Okon (2003), when evaluating plants under different $\mathrm{N}$ fertilizer rates, the contribution of diazotrophic bacteria can be different, equalizing the effect of $\mathrm{N}$ rates

Table 3. Plant height, first ear insertion height, stem diameter, SPAD index, shoot dry weight, and root length of maize plants as a function of seed inoculation with Bradyrhizobium japonicum (BJ) and co-inoculation with Azospirillum brasilense $(\mathrm{BJ}+\mathrm{AB})$ and $\mathrm{N}$ rates for maize crops.

\begin{tabular}{|c|c|c|c|c|c|c|}
\hline Inoculation & $\begin{array}{l}\text { Plant height } \\
(\mathrm{m})\end{array}$ & $\begin{array}{l}\text { First ear insertion height } \\
(\mathrm{m})\end{array}$ & $\begin{array}{l}\text { Stem diameter } \\
(\mathrm{mm})\end{array}$ & SPAD index & $\begin{array}{l}\text { Shoot dry weight } \\
(\mathrm{g})\end{array}$ & $\begin{array}{l}\text { Root length } \\
(\mathrm{cm})\end{array}$ \\
\hline BJ & $1.93 \mathrm{a}$ & $1.09 \mathrm{~b}$ & $20.21 \mathrm{a}$ & $55.73 \mathrm{a}$ & $159.08 \mathrm{a}$ & $29.10 \mathrm{a}$ \\
\hline $\mathrm{BJ}+\mathrm{AB}$ & $1.94 \mathrm{a}$ & $1.12 \mathrm{a}$ & $20.22 \mathrm{a}$ & $55.80 \mathrm{a}$ & $160.05 \mathrm{a}$ & $30.56 \mathrm{a}$ \\
\hline MSD & 0.04 & 0.005 & 0.19 & 0.39 & 13.15 & 5.68 \\
\hline \multicolumn{7}{|l|}{$\mathrm{N}$ rates $\left(\mathrm{kg} \mathrm{ha}^{-1}\right)$} \\
\hline 0 & 1.91 & 1.07 & 19.81 & 52.02 & 149.95 & 31.61 \\
\hline 50 & 1.94 & 1.11 & 20.09 & 55.47 & 155.92 & 29.21 \\
\hline 100 & 1.93 & 1.11 & 20.09 & 56.20 & 156.09 & 30.75 \\
\hline 150 & 1.94 & 1.11 & 20.38 & 57.30 & 160.11 & 29.00 \\
\hline 200 & 1.96 & 1.13 & 20.70 & 57.68 & 175.76 & 31.08 \\
\hline $\mathrm{F}$ value (linear) & -- & -- & $20.22 * *$ & $86.99 * *$ & -- & -- \\
\hline $\mathrm{F}$ value (quadratic) & -- & -- & -- & $10.24 * *$ & -- & -- \\
\hline
\end{tabular}

Means followed by the same letter are not significantly different by the $\mathrm{F}$ test at $p<0.05$. ${ }^{* *}=$ significant at $p<0.05$ by the $\mathrm{F}$ test; $\mathrm{CV}=$ Coefficient of variation; $\mathrm{MSD}=$ minimum significant difference.

Absence of response to seed inoculation with A. brasilense has been found for maize and other crops, in protected environment and field conditions. Verona et al. (2010) reported no significant difference for height and shoot dry weight of maize plants inoculated with Azospirillum sp. Different inoculation rates of Azospirillum sp. in maize seeds promoted no increases in root fresh weight and shoot dry weight (ROBERTO; SILVA; LOBATO, 2010), as also found for residual effect of co-inoculation in 
the present work.

Regarding the residual effect of coinoculation, Brum et al. (2016) evaluated maize production components under inoculation with $A$. brasilense and found similar results for first ear insertion height, which had significant differences for plants without $(0.99 \mathrm{~m})$ and with $(1.05 \mathrm{~m}) A$. brasilense.

Stem diameter had no significant response to residual effect of co-inoculation, as also found by Brum et al. (2016) and Dartora et al. (2013). This was probably because of the $\mathrm{N}$ rates used in combination with the co-inoculation; high $\mathrm{N}$ rates inhibit bacteria, and low $\mathrm{N}$ rates favor them.
The maize stem diameter as a function of topdressing with $\mathrm{N}$ rates showed an increasing linear response as the $\mathrm{N}$ rates were increased (Figure 1). Similar results were reported by Morais et al. (2015), who found that $\mathrm{N}$ fertilizer applications promote maize plant development and increase chlorophyll and nutrient contents, with increasing activity of urease and phosphatase enzymes, which are related to ammonium and inorganic phosphorus availability in the rhizosphere. According to Kappes et al. (2013), increases in stem diameter are beneficial for maize crop because a large stem prevents the plant from breaking, thus hindering lodging.

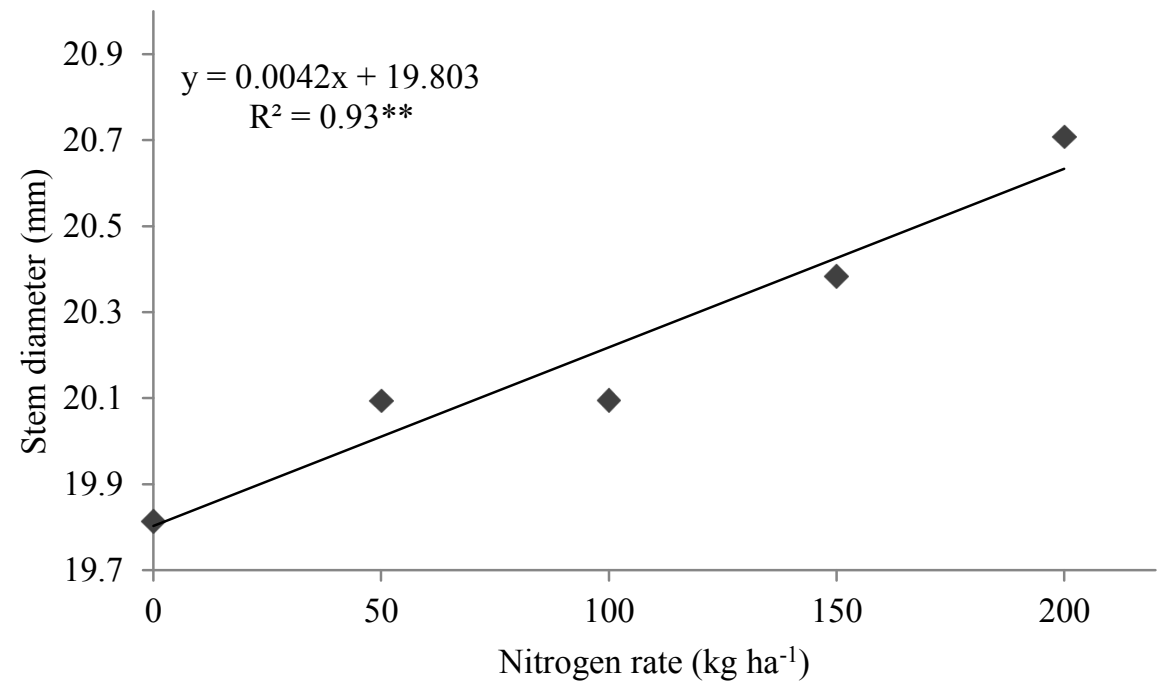

Figure 1. Stem diameter of maize plants as a function of the $\mathrm{N}$ rates.

The SPAD index had a quadratic response to the increases in $\mathrm{N}$ rates, with maximum value at the rate of $145.25 \mathrm{~kg} \mathrm{ha}^{-1}$ (Figure 2). This result is explained by the $\mathrm{N}$ function in the metabolism of plants and in the protein and chlorophyll biosynthesis (MORAIS et al., 2015). Similar results were reported by Morais et al. (2015), who found that chlorophyll contents in maize genotypes were sensitive to $\mathrm{N}$ availability in the environment.

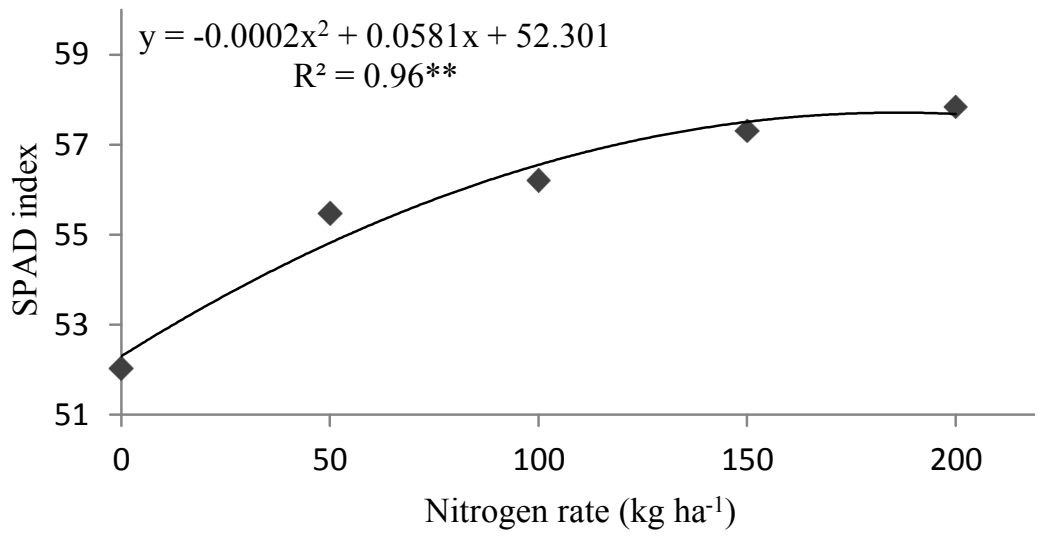

Figure 2. SPAD index in maize plants as a function of the $\mathrm{N}$ rates. 
The maize root length had no response to the residual effect of inoculation and to $\mathrm{N}$ rates, nor to their interaction; whereas the root dry weight and volume were affected by the isolated factors and by their interaction (Table 4). Studies have shown that effects of Azospirillum sp. are due to morphological and physiological changes in the roots of inoculated plants, which increase water and nutrient absorptions (SABUNDJIAN, 2016), but these effects not always increase root length, and they can increase root thickness.

Table 4. Root length, root dry weight, and root volume as a function of $\mathrm{N}$ rates and residual effect of seed inoculation and co-inoculation on maize crops succeeding soybean crops.

\begin{tabular}{lccc}
\hline \multicolumn{1}{c}{ Source of variation } & $\begin{array}{c}\text { Root length } \\
\mathrm{cm}\end{array}$ & $\begin{array}{c}\text { Root dry weight } \\
\mathrm{g}\end{array}$ & $\begin{array}{c}\text { Root volume } \\
\mathrm{cm}^{3}\end{array}$ \\
\hline F values & & & $70.33^{*}$ \\
Inoculation (I) & $1.23^{\mathrm{ns}}$ & $47.93^{*}$ & $28.00^{* *}$ \\
$\mathrm{~N}$ rates (N) & $1.88^{\mathrm{ns}}$ & $13.37^{* *}$ & $6.34^{*}$ \\
$\mathrm{I} \times \mathrm{N}$ & $2.37^{\mathrm{ns}}$ & $4.55^{*}$ & 2.64 \\
\hline $\mathrm{CV} \mathrm{1} \mathrm{( \% )}$ & 12.13 & 8.91 & 15.17 \\
CV 2 (\%) & 11.44 & 27.83 & 14.34 \\
CV 3 (\%) & 9.42 & 18.93 & 82.5 \\
\hline Overall mean & 29.83 & 45.11 & 8 \\
\hline
\end{tabular}

ns, ${ }^{* *}, *=$ not significant, significant at $p<0.01$, and significant at $p<0.05$ by the $\mathrm{F}$ test; $\mathrm{CV}=$ Coefficient of variation.

The description of the interaction between inoculation and $\mathrm{N}$ rates for the maize root dry weight and volume is shown in Table 5. There was no response to the factors residual effect of coinoculation and $\mathrm{N}$ rates, nor to their interaction, except for root length. The interaction between residual effect of co-inoculation and $\mathrm{N}$ rates was significant for root dry weight and volume. According to Morais et al. (2015), the success of bacteria of the genus Azospirillum depends on several factors, such as soil $\mathrm{N}$ fertilization, but it not always ensures the success of inoculation, as found in the present work.

Table 5. Root dry weight $(\mathrm{g})$ and volume $\left(\mathrm{cm}^{3}\right)$ as a function of seed inoculation with Bradyrhizobium japonicum (BJ) and co-inoculation with Azospirillum brasilense (BJ+AB).

\begin{tabular}{|c|c|c|c|c|c|}
\hline \multirow{2}{*}{ Inoculation } & \multicolumn{5}{|c|}{$\mathrm{N}$ rates $\left(\mathrm{kg} \mathrm{ha}^{-1}\right)$} \\
\hline & 0 & 50 & 100 & 150 & 200 \\
\hline \multicolumn{6}{|c|}{ Root dry weight (g) } \\
\hline$\overline{\mathrm{BJ}}$ & $22.23 \mathrm{a}$ & $39.46 \mathrm{a}$ & $36.94 \mathrm{a}$ & $45.77 \mathrm{~b}$ & $55.76 \mathrm{~b}$ \\
\hline $\mathrm{BJ}+\mathrm{AB}$ & $19.99 \mathrm{a}$ & $37.68 \mathrm{a}$ & $39.24 \mathrm{a}$ & $74.09 \mathrm{a}$ & $79.99 \mathrm{a}$ \\
\hline $\mathrm{CV}(\%)$ & & & 18.93 & & \\
\hline $\mathrm{I} \times \mathrm{N}$ interaction & (F value) & & & & \\
\hline N(BJ) Linear & $22.13 * *$ & & & & \\
\hline N(BJ) Quadratic & $0.02^{\mathrm{ns}}$ & & & & \\
\hline $\mathrm{N}(\mathrm{BJ}+\mathrm{AB})$ Linear & $100.58 * *$ & & & & \\
\hline $\mathrm{N}(\mathrm{BJ}+\mathrm{AB})$ Quadratic & $0.27^{\mathrm{ns}}$ & & & & \\
\hline \multicolumn{6}{|c|}{ Root volume $\left(\mathrm{cm}^{3}\right)$} \\
\hline BJ & $53.75 \mathrm{a}$ & $65.83 \mathrm{a}$ & $85.00 \mathrm{a}$ & $98.75 \mathrm{a}$ & $92.50 \mathrm{~b}$ \\
\hline $\mathrm{BJ}+\mathrm{AB}$ & $48.75 \mathrm{a}$ & $60.00 \mathrm{a}$ & $74.16 \mathrm{a}$ & $105.00 \mathrm{a}$ & $141.25 \mathrm{a}$ \\
\hline $\mathrm{CV}(\%)$ & & & 14.84 & & \\
\hline $\mathrm{I} \times \mathrm{N}$ interaction & (F value) & & & & \\
\hline N(BJ) Linear & $26.13 * *$ & & & & \\
\hline N(BJ) Quadratic & $2.71^{\mathrm{ns}}$ & & & & \\
\hline $\mathrm{N}(\mathrm{BJ}+\mathrm{AB})$ Linear & $113.8^{*}$ & & & & \\
\hline $\mathrm{N}(\mathrm{BJ}+\mathrm{AB})$ Quadratic & $1.80^{*}$ & & & & \\
\hline
\end{tabular}

Means followed of same letter in the columns are not different by the Tukey's test $(p<0.05)$; ns, **,* = not significant, significant at $p<0.01$, and significant at $p<0.05$ by the $\mathrm{F}$ test. 
The highest $\mathrm{N}$ rates (150 and $\left.200 \mathrm{~kg} \mathrm{ha}^{-1}\right)$ combined with the inoculation with $A$. brasilense increased the root dry weight; and the $\mathrm{N}$ rate of 200 $\mathrm{kg} \mathrm{ha}{ }^{-1}$ combined with the inoculation with $A$. brasilense increased root volume (Table 5). According to Siqueira et al. (1999), there is an increase of root density (secondary emergence and surface roots) of plants colonized by Azospirillum sp. because of the production of phytohormones by the bacteria, changing not only the growth of roots, but their morphology and density.

The root dry weight and volume of plants treated with $\mathrm{N}$ fertilization had linear increases as the $\mathrm{N}$ rates were increased (Figure $3 \mathrm{~A}$ and 3B), regardless of the residual effect of co-inoculation.

A

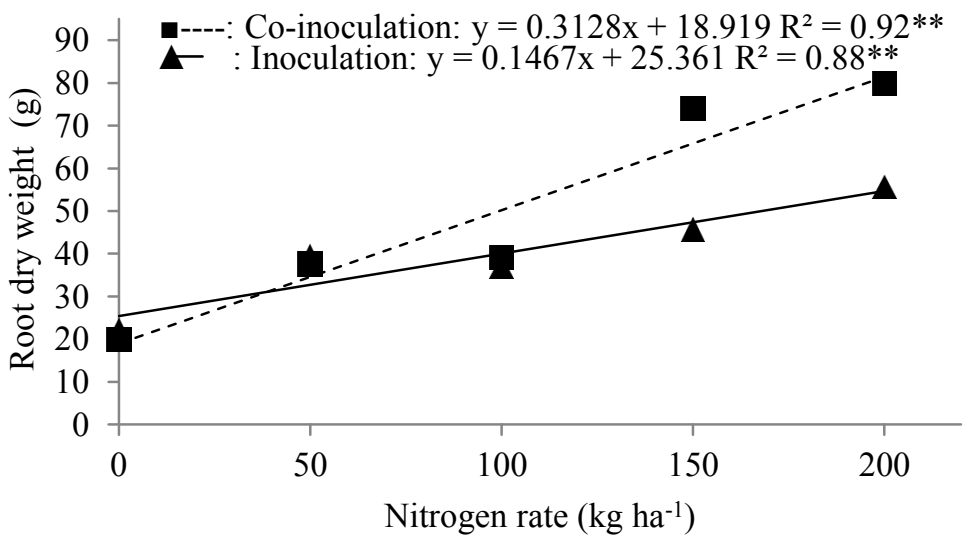

B

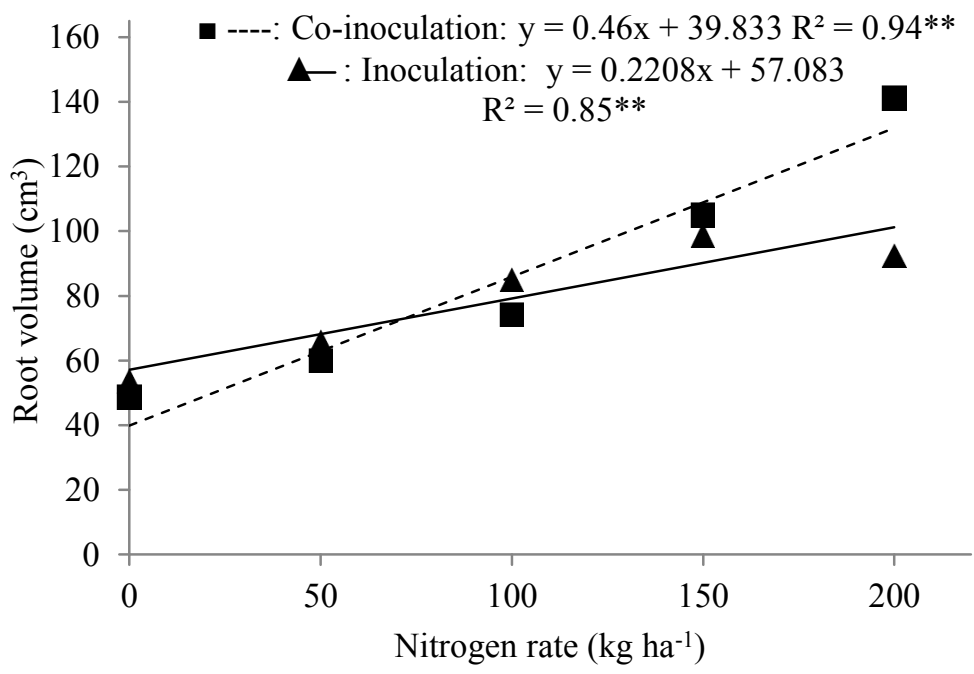

Figure 3. Maize root dry weight (A) and volume (B) as a function of $\mathrm{N}$ rates, with and without residual effect of coinoculation with Azospirillum brasilense.

The effect of inoculation with $A$. brasilense on maize root was mainly due to two mechanisms. The first is the bacteria atmospheric $\mathrm{N}$ fixing capacity (DOBBELAERE; VANDERLEYDEN; OKON, 2003), which can practically supply the nutrient required for the plants' development (MÜLLER et al., 2016). The second is the production of hormones, such as auxins, gibberellins, and cytokines, which affect root morphology and physiology, improving surface water and nutrient absorption (PERIN et al., 2003), which may contribute to increases in root dry weight and volume and $\mathrm{N}$ absorption. Moreover, the interaction between plants and bacteria has several effects that can interfere with the results, such as strain type, plant and bacteria nutritional status, plant genotype, environmental conditions, and competition with other microorganisms (QUADROS et al., 2014).

The productive variables were not affected by the residual effect of co-inoculation (Table 6); however, the $\mathrm{N}$ fertilizer rates significantly affected ear length, number of grains per ear, and grain yield, and no significant interaction was found between the factors for these productive characteristics. 
A. C. T. F. CÂNDIDO et al.

Table 6. Ear length, ear diameter, number of grains per ear, 1000-grain weight, and grain yield as a function of $\mathrm{N}$ rates and residual effect of seed inoculation and co-inoculation on maize crops succeeding soybean crops.

\begin{tabular}{|c|c|c|c|c|c|}
\hline Source of variation & $\begin{array}{l}\text { Ear length } \\
(\mathrm{cm})\end{array}$ & $\begin{array}{c}\text { Ear diameter } \\
(\mathrm{mm})\end{array}$ & Number of grains per ear & $\begin{array}{l}\text { 1000-grain weight } \\
(\mathrm{g})\end{array}$ & $\begin{array}{c}\text { Grain yield } \\
\left(\mathrm{kg} \mathrm{ha}^{-1}\right)\end{array}$ \\
\hline \multicolumn{6}{|l|}{ F value } \\
\hline Inoculation (I) & $1.85^{\mathrm{ns}}$ & $0.88^{\mathrm{ns}}$ & $3.70^{\mathrm{ns}}$ & $0.97^{\mathrm{ns}}$ & $5.97^{\mathrm{ns}}$ \\
\hline $\mathrm{N}$ rates $(\mathrm{N})$ & $14.24 * *$ & $2.79^{\mathrm{ns}}$ & $10.18 * *$ & $0.74^{\mathrm{ns}}$ & $6.65 * *$ \\
\hline $\mathrm{I} \times \mathrm{N}$ & $1.95^{\mathrm{ns}}$ & $1.56^{\mathrm{ns}}$ & $1.84^{\mathrm{ns}}$ & $1.09^{\mathrm{ns}}$ & $1.80^{\mathrm{ns}}$ \\
\hline CV $1(\%)$ & 3.61 & 5.14 & 4.16 & 6.67 & 12.32 \\
\hline CV $2(\%)$ & 3.00 & 1.82 & 5.15 & 6.35 & 9.29 \\
\hline CV $3(\%)$ & 2.71 & 1.67 & 5.83 & 4.98 & 10.40 \\
\hline Overall mean & 15.59 & 44.81 & 480.74 & 243.82 & $8,204.74$ \\
\hline
\end{tabular}

$\mathrm{ns}, * * *=$ not significant, significant at $p<0.01$, and significant at $p<0.05$ by the $\mathrm{F}$ test; $\mathrm{CV}=$ Coefficient of variation.

Marini et al. (2015) evaluated the growth and yield responses of maize hybrids to inoculation with A. brasilense and $\mathrm{N}$ fertilization rates and found no effect of the bacteria on grain yield, as also found in the present work for the residual effect of coinoculation.

Treatments with $A$. brasilense found in several studies under different edaphoclimatic conditions have shown different results, with increases in yield due to inoculation with these bacteria (BRACCINI et al., 2012; KAPPES et al., 2013, MAZZUCHELLI; SOSSAI; ARAÚJO, 2014). However, the residual effect of $A$. brasilense on the soil increased root development, but was not enough to generate effect on yield in the environmental conditions of the present study.

Goes et al. (2012) evaluated the maize hybrid DKB 350 and found similar results, with topdressing of $\mathrm{N}$ rates affecting ear diameter; they reported that this characteristic is related to grain filling and number of grain rows per ear, which is also affected by the plants' genetics.

Ear length and number of grains per ear increased linearly as the $\mathrm{N}$ rates were increased (Table 7; Figure 4).

Table 7. Ear length, ear diameter, number of grains per ear, 1000-grain weight, and grain yield as a function of seed inoculation with Bradyrhizobium japonicum (BJ) and co-inoculation with Azospirillum brasilense $(\mathrm{BJ}+\mathrm{AB})$ and $\mathrm{N}$ rates for maize crops.

\begin{tabular}{cccccc}
\hline Inoculation & $\begin{array}{c}\text { Ear length } \\
(\mathrm{cm})\end{array}$ & $\begin{array}{c}\text { Ear diameter } \\
(\mathrm{mm})\end{array}$ & Number of grains per ear & $\begin{array}{c}1000 \text {-grain weight } \\
(\mathrm{g})\end{array}$ & $\begin{array}{c}\text { grain yield } \\
\left(\mathrm{kg} \mathrm{ha}^{-1}\right)\end{array}$ \\
\hline BJ & $15.71 \mathrm{a}$ & $45.15 \mathrm{a}$ & $486.83 \mathrm{a}$ & $246.35 \mathrm{a}$ & $8595.2 \mathrm{a}$ \\
$\mathrm{BJ}+\mathrm{AB}$ & $15.47 \mathrm{a}$ & $44.47 \mathrm{a}$ & $474.64 \mathrm{a}$ & $241.28 \mathrm{a}$ & $7814.2 \mathrm{a}$ \\
\hline MSD & 0.56 & 2.31 & 20.15 & 16.35 & 1017.31 \\
\hline${\text { N rates }\left(\mathrm{kg} \mathrm{ha}^{-1}\right)}$ & & & & & \\
0 & 14.73 & 44.30 & 445.95 & 238.68 & 7150.5 \\
50 & 15.59 & 45.27 & 476.54 & 249.09 & 8400.2 \\
100 & 15.30 & 44.33 & 479.15 & 238.97 & 8062.0 \\
150 & 15.97 & 44.89 & 477.89 & 245.65 & 8345.1 \\
200 & 16.36 & 45.28 & 524.17 & 246.71 & 9065.7 \\
\hline F value (linear) & $48.28^{* *}$ & -- & $54.97^{* *}$ & -- & $19.63^{* *}$ \\
F value (quadratic) & -- & -- & -- & -- & -- \\
\hline
\end{tabular}

Means followed by the same letter are not significantly different by the $\mathrm{F}$ test at $p<0.05$. $* *=$ significant at $p<0.05$ by the $\mathrm{F}$ test $\mathrm{CV}=$ Coefficient of variation; $\mathrm{MSD}=$ minimum significant difference. 

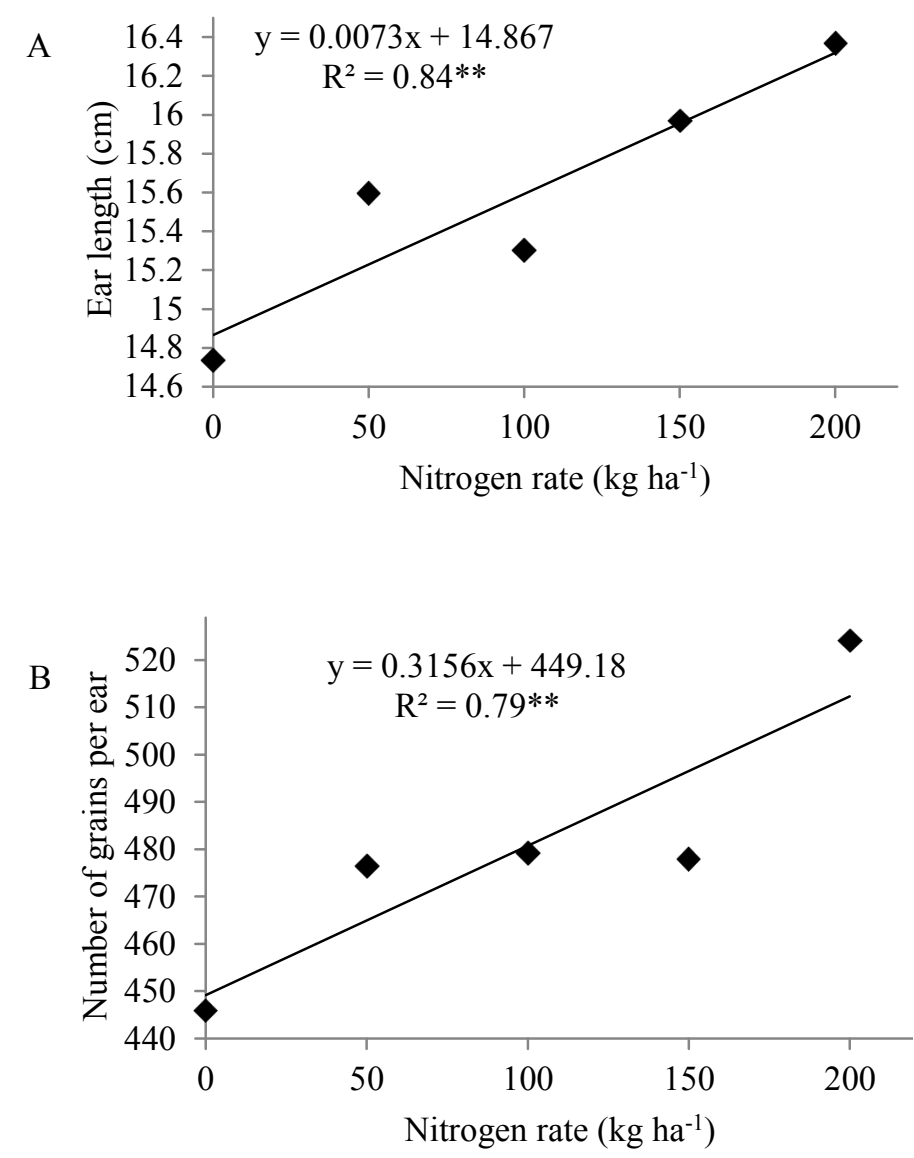

Figure 4. Ear length and number of grains per ear of maize plants as a function of $\mathrm{N}$ rates.

Maize grain yield increased linearly as the $\mathrm{N}$ rates were increased (Figure 5), up to the rate $200 \mathrm{~kg} \mathrm{ha}^{-1}$, not showing its maximum response, indicating that the grain yield could be higher at higher $\mathrm{N}$ rates. Biscaro et al. (2011) found similar results, with increases in maize grain yield as the $\mathrm{N}$ fertilizer rates were increased.

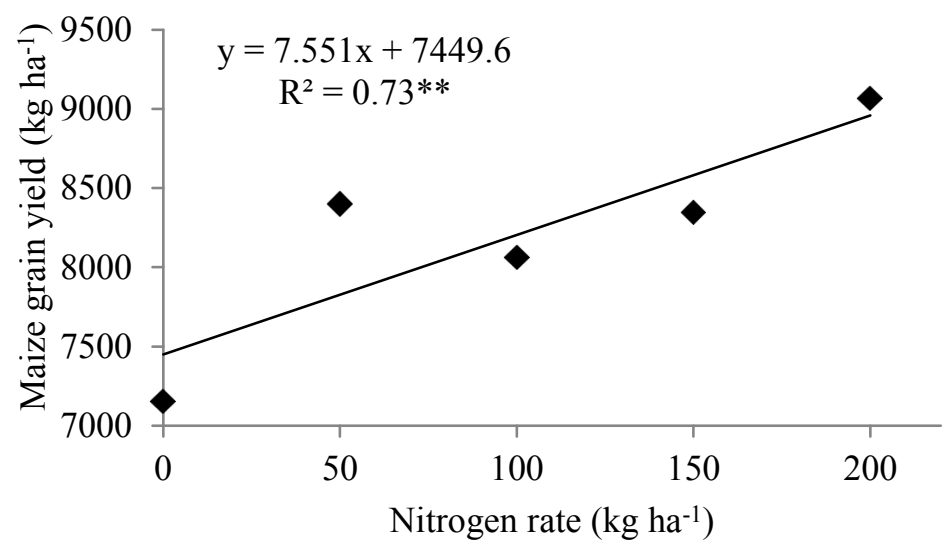

Figure 5. Maize grain yield as a function of $\mathrm{N}$ rates.

Increasing linear response to $\mathrm{N}$ rates for most productive characteristics of maize crops is expected, since $\mathrm{N}$ is an essential nutrient to obtain high yields due to the large demand of plants, thus, low availability of $\mathrm{N}$ in the soil limits maize grain yield (DOTTO et al., 2010). 


\section{CONCLUSION}

The co-inoculation of soybean seeds and its residual effect on the maize plants increased the root dry weight of both crops; however, these increases were not found for the vegetative characteristics plant height, first ear insertion height, stem diameter, SPAD index, and shoot dry weight; nor for the reproductive characteristics ear length, ear diameter, number of grains per ear, 1000-grain weight, and gran yield of maize plants.

Maize grain yield and most evaluated characteristics showed increasing linear response to increases in $\mathrm{N}$ rates, and indicated responses to rates above $200 \mathrm{~kg} \mathrm{ha}^{-1}$.

\section{ACKNOWLEDGEMENTS}

The authors thank the Mato Grosso Research Support Foundation (FAPEMAT) for granting the scholarship to the first author.

\section{REFERENCES}

ALBUQUERQUE, A. W. et al. Plantas de cobertura e adubação nitrogenada na produção de milho em sistema de plantio direto. Revista Brasileira de Engenharia Agrícola e Ambiental, 17: 721-726, 2013.

ALVES, V. M. C. et al. In: RIBEIRO, A. C.; GUIMARÃES, P. T. G.; ALVAREZ VENEGAS, V. H. (Ed.). Recomendações para o uso de corretivos e fertilizantes em Minas Gerais: $5^{\text {a }}$ aproximação. Viçosa, MG: Comissão de Fertilidade do Solo do Estado de Minas Gerais, 1999. cap. 18, p. 314-316.

BARASSI, C. A. et al. Potencialidad de Azospirillum en optimizer el crecimiento vegetal bajo condiciones adversas. In: CASSÁN, F. D.; GARCIA DE SALAMONE, I. (Eds.) Azospirillum sp.: cell physiology, plant interactions and agronomic research in Argentina. Argentina: Asociación Argentina de Microbiologia, 2008. p. 4959.

BASTOS, E. A. et al. Doses e formas de parcelamento de nitrogênio para a produção de milho sob plantio direto. Revista Ciência Agronômica, 39: 275-280, 2008.

BISCARO, G. A. et al. Desempenho do milho safrinha irrigado submetido a diferentes doses de nitrogênio via solo e foliar. Agrarian, 4: 10-19, 2011.
BRACCINI, A. L. et al. Seed inoculation with Azospirillum brasilense associated with the use of bioregulators in maize. Revista Caatinga, 25: 58-64, 2012.

BRUM, M. S. et al. Components of corn crop yield under inoculation with Azospirillum brasilense using integrated crop-livestock system. Acta Scientiarum Agronomy, 38: 485-492, 2016.

CHIBEBA, A. M. et al. Co-inoculation of soybean with Bradyrhizobium and Azospirillum promotes early nodulation. American Journal of Plant Sciences Coulterville, 6: 1641-1649, 2015.

DARTORA, J; et al. Adubação nitrogenada associada à inoculação com Azospirillum brasilense e Herbaspirillum seropedicae na cultura do milho. Revista Brasileira de Engenharia Agrícola e Ambiental, 17: 1023-1029, 2013.

DOBBELAERE, S.; VANDERLEYDEN, J.; OKON, Y. Plant growth-promoting effects of diazotrophs in the rhizosphere. CRC Critical Review in Plant Science, 22: 107-149, 2003.

DOTTO, A. P. et al. Produtividade do milho em resposta à inoculação com Herbaspirillum seropedicae sob diferentes níveis de nitrogênio. Revista Brasileira de Ciências Agrárias, 5: 376$382,2010$.

EMPRESA BRASILEIRA DE PESQUISA AGROPECUÁRIA - EMBRAPA. Sistema Brasileiro de Classificação de Solos. 3. ed. Brasília, DF: Embrapa, 2013. 353 p.

EMPRESA DE PESQUISA ENERGÉTICA - EPE. Avaliação ambiental integrada da bacia hidrográfica do Rio Teles Pires. 2009. Disponível em: $\quad<$ http://www.epe.gov.br/MeioAmbiente/ Documents/AAI\%20Teles\%20Pires/AAI\%20Teles\% 20Pires\%20-\%20Relat\%C3\%B3rio\%20Final.pdf>. Acesso em: 01 dez. 2016.

FERREIRA, D. F. Sisvar: a computer statistical analysis system. Ciência e Agrotecnologia, 35: 1039-1042, 2011.

FIPKE, G. M. et al. Co-inoculation with diazotrophic bacteria in soybeans associated to urea topdressing. Ciência e Agrotecnologia, 40: 522-533, 2016.

GOES, R. J. et al. Nitrogênio em cobertura para o milho (Zea mays 1.) em sistema plantio direto na safrinha. Revista Brasileira de Milho e Sorgo, 11: 169-177, 2012.

JORDÃO, L. T. et al. Inoculação de Azospirillum brasilense nas sementes aumenta a produtividade do 
milho, economiza fertilizante e beneficia o meio ambiente. Cultivar Grandes Culturas, 144: 16-18, 2011.

JUGE, C. et al. Growth and biochemical responses of soybean to double and triple microbial associations with Bradyrhizobium, Azospirillum and arbuscular mycorrhizae. Applied Soil Ecology, 61: $147-157,2012$.

KAPPES, C. et al. Influência do nitrogênio no desempenho produtivo do milho cultivado na segunda safra em sucessão à soja. Pesquisa Agropecuária Tropical, 39: 251-259, 2009.

KAPPES, C. et al. Inoculação de sementes com bactéria diazotrófica e aplicação de nitrogênio em cobertura e foliar em milho. Semina: Ciências Agrárias, 34: 527-538. 2013.

MALAVOLTA, E.; VITTI, G. C.; OLIVEIRA, S. A. Avaliação do estado nutricional das plantas: princípios e aplicações. 2. ed. Piracicaba, SP: POTAFOS, 1997. 319 p.

MARINI, D. et al. Growth and yield of mayze hybrids in response to association with Azospirillum brasilense and nitrogen fertilization. Revista Ceres, 62: 117-123, 2015.

MAZZUCHELLI, R.C. L.; SOSSAI, B. F.; ARAÚJO, F. F. Inoculação de Bacillus subtilis e Azospirillum brasilense na cultura do milho. Colloquium Agrariae, 10: 40-47, 2014.

MORAIS, T. P. et al. Aspectos morfofisiológicos de plantas de milho e bioquímico do solo em resposta à adubação nitrogenada e à inoculação com Azospirillum brasilense. Revista Ceres, 62: 589596, 2015.

MÜLLER, T. M. I. et al. Combination of inoculation methods of Azospirilum brasilense with broadcasting of nitrogen fertilizer increases corn yield. Ciência Rural, 46: 210-215, 2016.

NOVAIS, R. F. Soja. In: RIBEIRO, A. C.; GUIMARÃES, P. T. G.; ALVAREZ VENEGAS, V. H. (Eds.). Recomendações para o uso de corretivos e fertilizantes em Minas Gerais: $5^{\text {a }}$ aproximação. Viçosa, MG: Comissão de Fertilidade do Solo do Estado de Minas Gerais, 1999. cap. 18, p. 290-291.

PERIN, L. M. et al. Avaliação da capacidade de estabelecimento endofítico de estirpes de Azospirillum e Herbaspirillum em milho e arroz. Revista Agronomia, 37: 47-53, 2003.
QUADROS, P. D. et al. Desempenho agronômico a campo de híbridos de milho inoculados com Azospirillum. Revista Ceres, 61: 209-218, 2014.

ROBERTO, V. M. O.; SILVA, C. D.; LOBATO P. N. Resposta da cultura do milho à aplicação de diferentes doses de inoculante (Azospirillum brasilense) via semente. In: $28^{\circ}$ Congresso Nacional de Milho e Sorgo, 2010, Goiânia. Anais... Goiânia: Associação Brasileira de Milho e Sorgo. p. 2429. 2434.

SABUNDJIAN, M. T. Consórcio de milho e Urochloa ruziziensis e inoculação com Azospirillum brasilense e seu efeito residual associado à adubação nitrogenada em feijoeiro de inverno. 2016. 173 f. Tese (Doutorado em Agronomia: Área de Concentração em Sistemas de Produção) - Universidade Estadual Paulista, Ilha Solteira, 2016.

SIQUEIRA, J. O. et al. Inter-relação fertilidade, biologia do solo e nutrição de plantas. 1. Ed. Lavras, MG: SBCS, 1999. 818 p.

SORATTO, R. P. et al. Fontes alternativas e doses de nitrogênio no milho safrinha em sucessão à soja. Revista Ciência Agronômica, 41: 511-518, 2010.

VERONA, D. J. et al. Tratamento de sementes de milho com Zeavit ${ }^{\circledR}$, Stimulate ${ }^{\circledR}$ e inoculação com Azospirillum sp. In: $28^{\circ}$ Congresso Nacional de Milho e Sorgo, 2010, Goiânia. Anais... Goiânia: Associação Brasileira de Milho e Sorgo. p. 37313737.

ZUFFO, A. M. et al. Co-inoculation of Bradyrhizobium japonicum and Azospirillum brasilense in the soybean crop. Revista de Ciências Agrárias, 38: 87-93, 2015. 